\title{
IDENTIFICATION AND DESCRIPTION OF PROCESSES AT THE OPERATIONAL AND INFORMATION CENTRE OF THE FIRE AND RESCUE SERVICE OF THE CZECH REPUBLIC
}

\author{
DOI: 10.12776/QIP.V19I1.432
}

\author{
MAREK GAŠPARÍN
}

Received 2 December 2014, Revised 16 February 2015, Accepted 28 May 2015

\begin{abstract}
Purpose: The proposal of key processes at a workplace of the Operational and Information Centre (OIC) of the Fire and Rescue Service of the Czech Republic (FRS CR) and description necessities for a proper applying of the process management.
\end{abstract}

Methodology/Approach: Applying of process management at specific conditions.

Findings: The paper presents process diagrams of the key processes of the OIC and describes a continuity, concurrence and causality among them. The double role of institutions in the key processes is shown. A necessity of proper setting of process evaluation parameters is outlined.

Research Limitation/implication: The process management is not applied in full range yet. Creating of process maps, setting of process performance indicators, methods for processes performance measurement and applying of the risk management principles are needed.

Originality/Value of paper: The paper describes first activities in applying of the quality management at the FRS CR.

Keywords: processes; process management; customer; process evaluation; fire brigade 


\section{INTRODUCTION}

An external look at the Operational and Information Centre (OIC) of the Fire and Rescue Service of the Czech Republic (FRS CR) activities might evoke an opinion that it is not possible to apply process management to the workplace OIC. Despite it, it is possible to define the OIC processes and to apply process management. It is possible to define the process owner, the process inputs and outputs and to identify the customers and suppliers (Kemp, 2005). Inputs and outputs requirements can be set and process management tools can be used. And, although it is not easy, process performance parameters can be set and tools for process performance monitoring can be used (Nenadál, 2004). And moreover a risk management should be applied as an integral part of quality management (Cooper, 2004).

For a proper processes management it is, besides other things, indispensably necessary to know and describe all process activities, describe process inputs and outputs and to know relations between processes. The main purpose of the paper is to present key processes at such a specific workplace, as is the OIC, to describe their specifics and to nearer relations between them. All of that is inevitable in case of applying of any quality management model at OIC workplace, which is not performed in the Czech Republic yet.

There are practical experiences in the quality management (Schmidt, et al., 2009) and process management (Reineke, 2008) application at operational centres of the fire brigade in the traditional EU countries. Also there are experiences at application of the quality management in 112 callcentres (Modelo de Calidad, n.d.). But, there is an fundamental difference among the OIC FRS CR and mentioned workplaces abroad. No other operational centre of the fire brigade or 112 call centre carries out the same activities as OIC FRS of the Czech Republic.

\section{THE OPERATIONAL AND INFORMATION CENTRE OF FIRE AND RESCUE SERVICE}

To ensure the main tasks by the Act no. 238/2000 Coll. on Fire and Rescue Service of the Czech Republic (Act no. 238/2005, 2005) and by the Act no. 239/2000 Coll. on Integrated Rescue System (Act no. 239/2000, 2000), the Fire and Rescue Service of the Czech Republic uses, except for fire-fighting units, the Operational and Information Centre. The OIC FRS CR constitutes a workplace filling many specific tasks while emergency calls receiving, dealing with emergencies, as well as the state of emergency readiness.

The OIC FRS ensures receiving and processing calls on an emergency line 150, and receiving, evaluating and distributing calls on the emergency line 112 . Subsequently it ensures dispatching and directing rescue units, provides information support for the rescue units and deals with emergency solution at the operational level - information and coordinating of concerned organizations and institutions, cooperation of the integrated rescue system (IRS) services, etc. (see 
Figure 1). Moreover, the OIC ensures monitoring and concurrence of all emergency events and a security situation and operates a population warning systems.

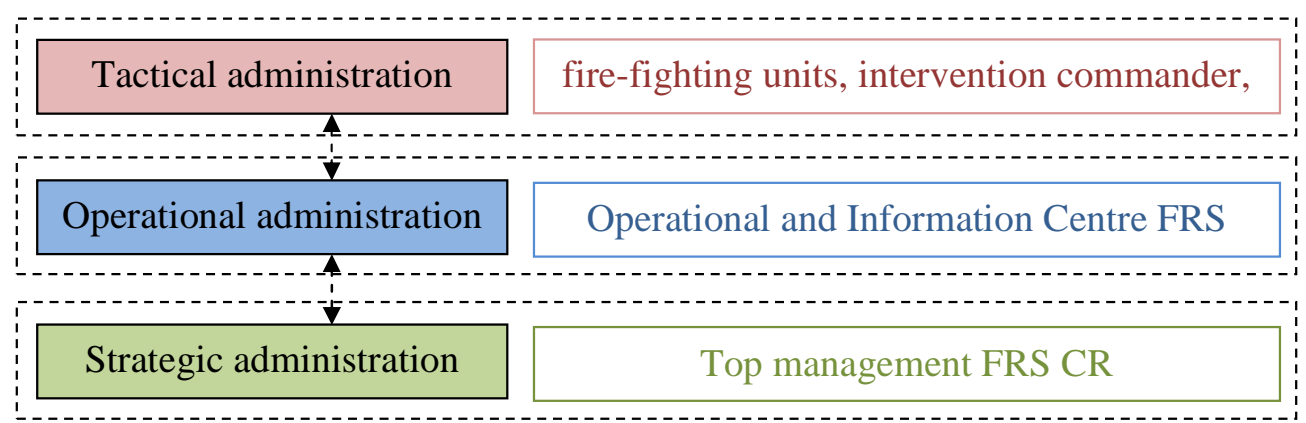

Figure 1 - The administrative levels of the emergency assistance

\section{PROCESSES AT THE OPERATIONAL AND INFORMATION CENTRE}

One of the basic principles of modern concepts of the quality management is a process administration and its applications. The process administration is a set of activities and procedures related to a process mapping and a defining, determining process inputs and outputs, the process owners specifying, and a process monitoring and a output measurement (Nenadál, Noskievičová and Petř́ková, 2008).

Like the processes of most organizations, the OIC FRS CR processes can be divided into:

- Control processes (management, planning, check-up activities, etc.),

- Supporting processes (IT support, maintenance and service, education and training, etc.),

- Key processes.

The main task of the paper is to present the key processes of the Operational and Information Centre FBS CR. At the text below is a more extensive description of the key processes carried out at the OIC:

$\mathrm{K} 1$ - the emergency calls receiving,

$\mathrm{K} 2$ - the dealing with emergencies (operational activities),

$\mathrm{K} 3$ - the security situation monitoring. 


\subsection{K1 - The emergency calls receiving}

According to the Act no. 127/2005 Coll. on Electronic Communications are the emergency calls 112 and 150 received to the OIC FRS CR. The emergency calls receiving process (see Figure 2) starts by answering an emergency call and finishes by sending a data record (electronic information about what happened, where it happened and information about a caller), by switching the call to another rescue service or only by communication with the caller.

The process of receiving an emergency calls includes an emergency caller and an operator of the OIC. If it is necessary, the emergency call can be transferred to an operator of another IRS service. In case of a foreign-language call, the call can be transferred or a 3-member conference can be created by a foreign-language proficient operator of any OIC in the Czech Republic.

The specifics of this process are a large number of non-emergency calls (abuse, misuse and inadvertent calls, pocket calls) and a high mental workload of the OIC call takers.

Another specific is the customer, the person calling the emergency line. In case of an emergency it may be a person involved in the emergency (the injured or endangered person himself, endangered person's family member, witness of a crime or an accident, etc.). In this case it is not always easy to get all required emergency information (what happened, where it happened, etc.), and sometimes even the call-takers can't get them.

Each emergency call is different, specific and affected by many circumstances. All that may influence the communication with the caller. The callers can report different kinds of emergency, from very serious to relatively trivial ones (health problems, traffic accidents, floods, or lost house keys). But still, at all emergency calls the call-takers have to record three basic pieces of information - what happened, where it happened and caller identification. 


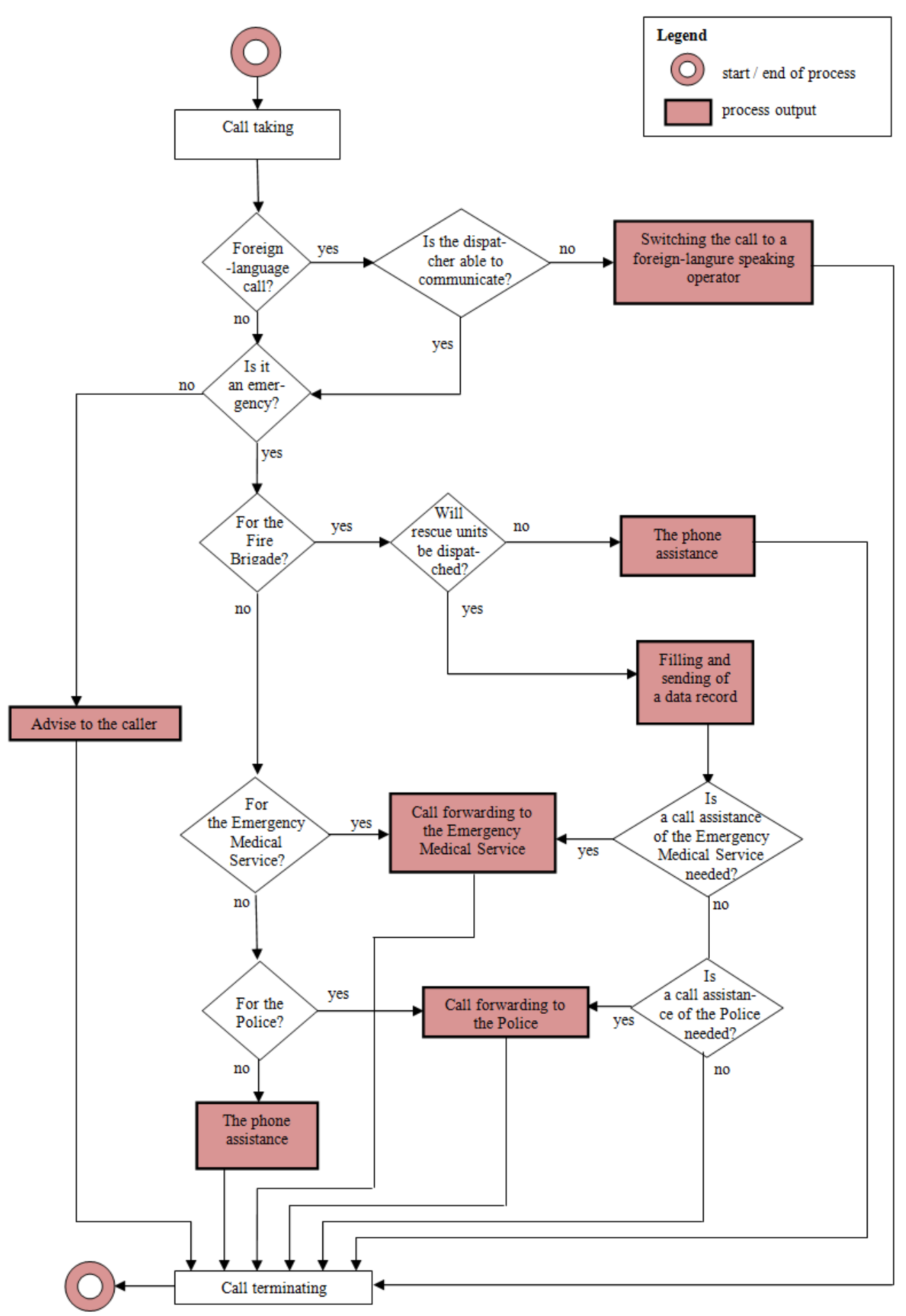

Figure 2-K1 - emergency calls receiving - the process diagram 


\subsection{K2 - The dealing with the emergencies (operational activities)}

The dealing with the emergencies process (see Figure 3) primarily involves the OIC FRB and the fire-fighting units (FFU - the professional and volunteer fire brigades). Except for them, the process may include other IRS services, rescue units (the Mountain Rescue Service, etc.), a government and an administration, institutions, etc. The process begins by taking an information about the event and continues by dispatching rescue units and potentially by informing other rescue services. The process is terminated by the FFU base returning and preparedness and closing the event at the operational level.

The specifics of this process are:

- the OIC operators are usually involved in dealing with more emergencies at the same time,

- a high strain in a initial phase of the emergency,

- a duration of the emergency can be in a range from minutes to days.

Dealing with the emergencies is the quite complicated process to describe. There are no two emergency events which would be the same. Each one has got its own specifications and can last from minutes to days. Each dealing with the emergency depends on the cooperation between the OIC and the deployed fire brigades. It is not possible to forecast the way to deal with an emergency event (fire, traffic accident, technical intervention, flood, etc.). 


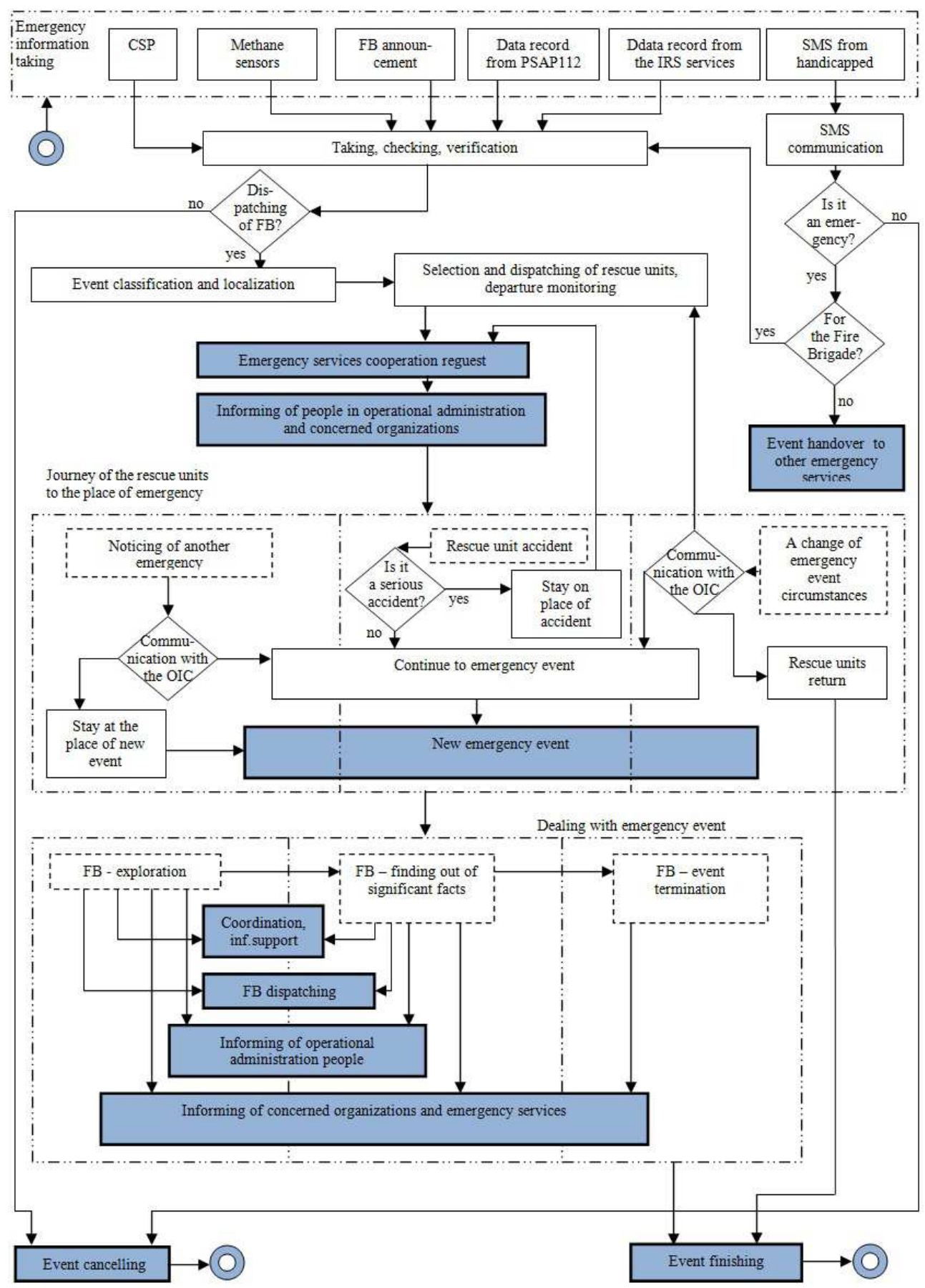

Legend

start/end of process
process output
CSP-Central Security Panel

IRS-Integrated Rescue System

OIC - Operational and Information Centre
PSAP - Public Safety Answering Point FB - Fire Brigades

Figure $3-K 2$ - the dealing with the emergencies - the process diagram 


\subsection{K3 - The security situation monitoring}

Into the security situation monitoring process (see figure 4) belong all activities associated with security monitoring - a flood and climate situation, faults and failures of technology, utilities, networks, transport and traffic, a state of elements of a critical infrastructure, movement and readiness of the FFU and the rescue services.

The specific of the process is that it is a non-stop process.

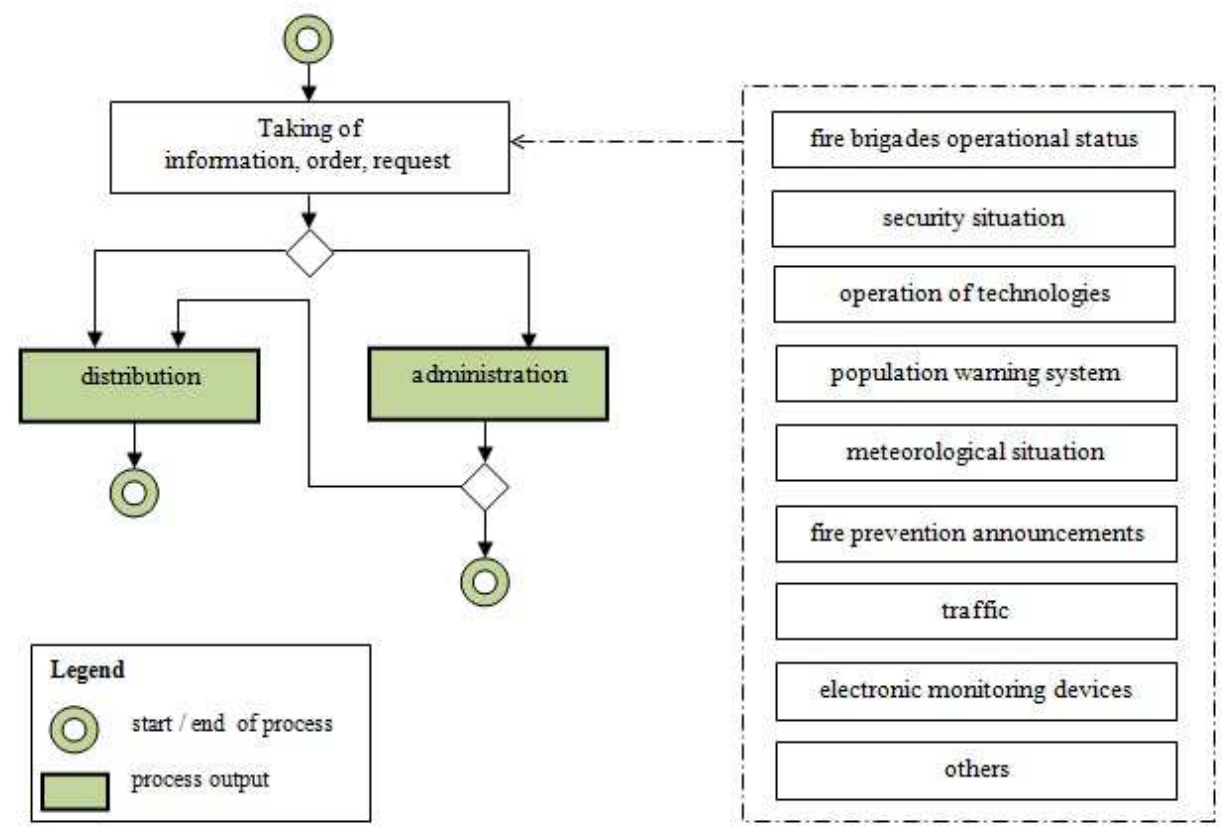

Figure 4 - Security situation monitoring - the process diagram

\section{THE CONTINUITY AND CAUSALITY OF THE KEY PROCESSES}

It seems that a direct and logical succession is only between the $\mathrm{K} 1$ - the emergency calls receiving process and the $\mathrm{K} 2$ - dealing with the emergencies, but that is not true. The reality is that each key process can include both providing the process input for or receiving the output from the other key processes (see Figure 5). And except of that, each key process can receive input from or provide output for external and internal customers.

For example, the rescue units dispatched to solve an emergency can observe or be witnesses of another emergency on their way. That means, that the K2 dealing with the emergencies process provides the input for the $\mathrm{K} 1$ - the emergency calls receiving process. The same rescue unit on its way to the emergency can be involved in a traffic accident. In this case, the $\mathrm{K} 2$ - dealing 
with the emergencies process provides the input for the $\mathrm{K} 3$ - the security situation monitoring process (readiness of FFU).

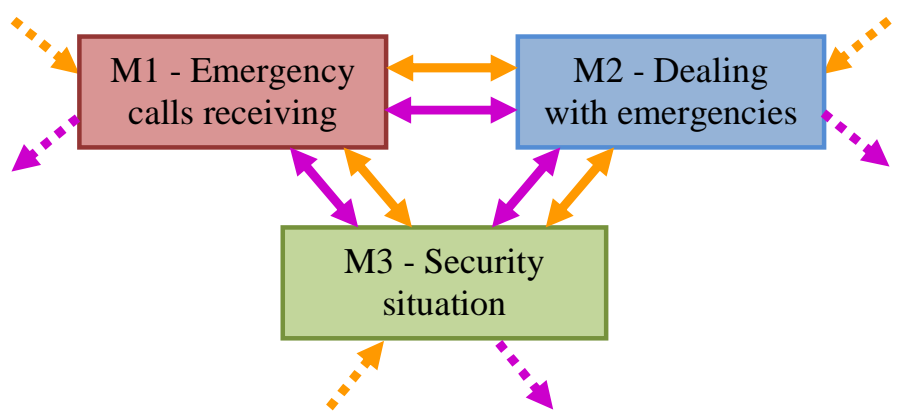

$$
\begin{aligned}
& \because n+1 \text { the external } \\
& \text { process inputs } \\
& \ldots \text { the external } \\
& \text { process outputs } \\
& \text { the internal } \\
& \text { process inputs } \\
& \longrightarrow \text { the internal } \\
& \text { process outputs }
\end{aligned}
$$

Figure 5 - The links among key processes - the inputs and outputs

There is the diagram of the time succession and concurrence of the OIC key processes at the Figure 6. There is clearly seen a considerable difference between the duration of the key processes on the diagram:

- $22 \mathrm{sec}$ average duration the $\mathrm{K} 1$ - emergency calls receiving process (Gašparín, 2014b),

- 1 hour 18 min average duration the $\mathrm{K} 2$ - dealing with the emergencies process (Gašparín, 2014a),

- non-stop the $\mathrm{K} 2$ - security situation monitoring process.

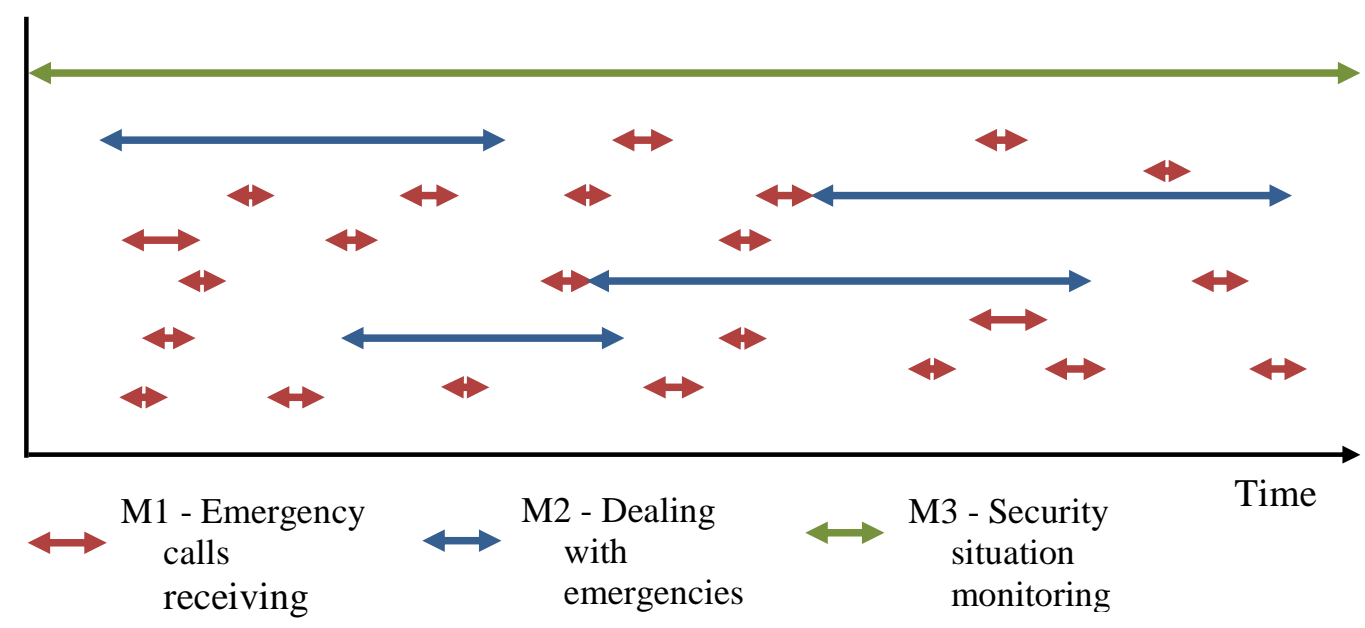

Figure 6 - The succession and concurrence of the key processes 


\section{THE PROCESS CUSTOMERS AND SUPPLIERS}

Generally, all rescue services, including the FRS CR, primarily provide service for the customers. To be able to carry out the main tasks the FRS CR uses its own suppliers. The same relationships concern the OIC, the OIC has got its own suppliers and customers. The range of the customers and suppliers of the OIC FRS is wider than it would seem. There is a diagram of the internal and external customers of the OIC at Figure 7.

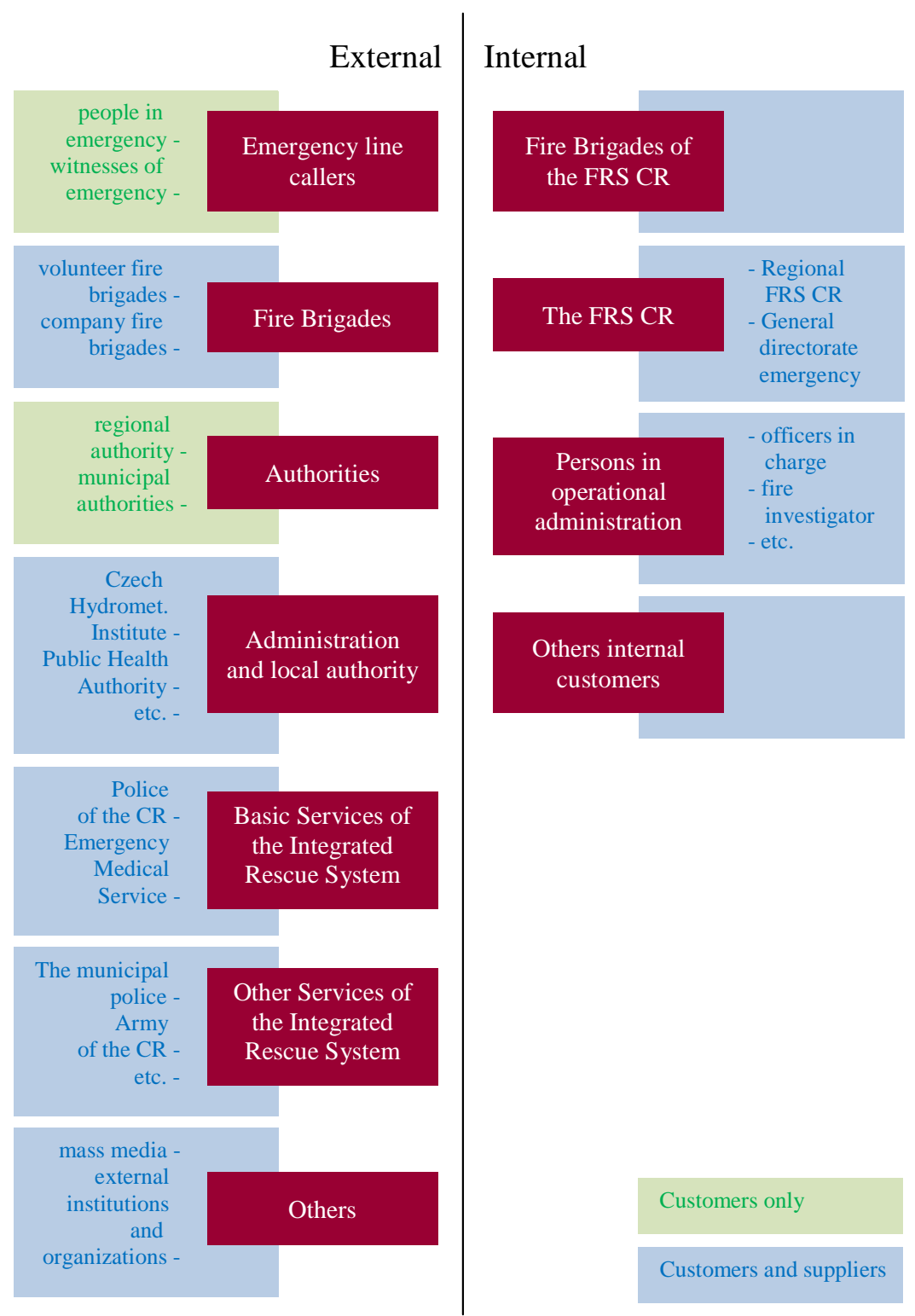

Figure 7 - The OIC FRS customers and suppliers 
The diagram also shows whether the customers only receive the output, or also provides the process input. It is a specific of the OIC processes that various subjects are customers and suppliers at the same time. The diagram shows that most of the OIC customers are OIC suppliers too.

\section{CONCLUSION}

The text approaches first practical experiences at the field of quality management at the OIC workplaces, which are related to key processes defining and description and customers and suppliers analysing. All these activities are just the first step to the application of the process management, which is the fundamental principle of all modern quality management systems. Next steps, that must be done are defining and description of other processes at the OIC workplace and creation of a process map, setting of process performance indicators and methods for processes performance measurement and evaluating and applying of the risk management principles as well.

It is suggested in performance measurement to focus on individuals, not on the workplace as a whole (Packova \& Karacsony, 2010). But individual's performance at OIC is widely affected by individual's experience and its knowhow. In that point of view, experience and knowledge are crucial elements of the process performance at the OIC FRS. That is why it would be suitable to create something like an "organisational memory" (Alwis, Hlupic and Rzevski, 2003) for training of the OIC dispatchers, to share good and bad practice and to increase the process performance.

The practice at the OIC FRS CR shows, that parameters for evaluation of process performance should be chosen very carefully. The example, for the emergency calls receiving a length of the call cannot be chosen as the only criterion. Of course, the length of the call is an important criterion, but it is affected by many significant circumstances - caller's psychological and physical condition, how much information is the caller able to report, the situation at the place of emergency, etc. That means that the length of call can be evaluated only in connection with the call content. It is also important to evaluate the ability of the dispatcher to control the call, his manner of behaviour and performing, But these factors are often evaluated subjectively and is important to prepare an appropriate evaluate methodology and to teach evaluators to use it.

\section{REFERENCES}

Act no. 127/2005 Coll. on Electronic Communications. Statue book of the Czech Republic. 2005, part 43.

Act no. 238/2000 Coll. on Fire and Rescue Service of the Czech Republic, 2000. Statue book of the Czech Republic. 2000, part 73. 
Act no. 239/2000 Coll. on Integrated Rescue System, 2000. Statue book of the Czech Republic. 2000, part 73.

Alwis, D., Hlupic, V. and Rzevski, G., 2003. Designing Organisational Memory in Knowledge-Intensive Companies: A Cause Study. In: Hlupic V., 2003, Knowledge and Business Process Management, 289 pages, ISBN 1-59140-074-0.

Cooper, D.F., Raymond, G., Grey, S. and Walker, P., 2004. Project Risk Management Guidelines. John Wiley \& Sons Ltd., 384 pages, ISBN 0-47002281-7.

Gašparín, M., 2014a. Emergency events analysis. [in-house publication of the Fire and Rescue service of Moravian-Silesian Region]

Gašparín M., 2014b. Emergency calls 112 and 150 analysis. Journal 112, 11(6), pp.16-19, ISSN 1213-7057.

Kemp, S., 2005. Quality Management Demystified, McGraw Hill Professional, 320 pages, ISBN 00-7148-305-5.

Modelo de Calidad, n.d., Calidad Certificada. [online] Available at http://pagina.jccm.es/justicia/112/compromisos/1330_certificacion.html [Accessed 5 December 2014].

Nenadál, J., Noskievičová, D. and Petř́́ková, R., 2008. Moderní management jakosti: principy, postupy, metody (Modern Quality Management: Principles, Procedures, Methods). 1st edition, Management Press, 377 pages.

Nenadál, J., 2004. Měrení v systémech managementu kvality (Measurement in Quality Management Systems). 2nd edition, Management Press, 335 pages, ISBN 80-7261-110-0.

Packova, V., Karacsony, P., 2010. Designing and Implementing Performance Management Systems. In: Taticchi P., 2010, Business Performance Measurement and Management, Springler-Verlag Berlin Heidelberg, 376 pages, ISBN 978-3642-04799-2.

Reineke, A., 2008. Qualitätsmanagement in der Interierten Leitstelle. BRANDSchutz Deutsche Feuerwehr-Zeitung, 6/2008, pp.114-116, ISSN 00069094

Schmidt, G., Schun J. and Hinterscheid U., 2009. Kostenneutrale Lösung für die Qualitätssicherung der Leitstellenarbeit. BRANDSchutz Deutsche FeuerwehrZeitung, 2/2009, pp.112-115, ISSN 0006-9094.

\section{ABOUT THE AUTHOR}

Marek Gašparín Ing., Integrated Security Centre Department of the Fire and Rescue Service of Moravian-Silesian Region, Czech Republic. e-mail: marek.gasparin@hzsmsk.cz 